UDC $004.8(045)$

DOI: $10.18372 / 1990-5548.56 .12931$

${ }^{1}$ V. M. Sineglazov,

${ }^{2}$ I. S. Shvaliuk

\title{
INVESTIGATION OF BLADE ATTACK ANGLE VALUE ON VERTICAL AXIAL WIND POWER PLANT
}

\author{
${ }^{1,2}$ Aviation Computer-Integrated Complexes Department, Educational\&Scientific Institute of Information- \\ Diagnostics Systems, National Aviation University, Kyiv, Ukraine \\ E-mails: 1svm@nau.edu.ua, ${ }^{1}$ shvaluk95@gmail.com
}

\begin{abstract}
In this paper, the efficiency of the vertical-axial wind power plant at various wind speeds depending on the angle of attack of the rotor blades was investigated. The object of the investigation was a three-bladed Darrieus rotor. During the modeling we used the viscous gas flow model with averaging of turbulent characteristics (Reynolds-averaged Navier-Stokes equations for an incompressible fluid. These investigations would allow us to develop new principles for constructing vertical-axial wind turbines with a variable angle of attack of the blades in order to increase the energy efficiency of verticalaxis wind turbine.
\end{abstract}

Index Terms - Vertical-axis rotor; Darrieus rotor; angle of attack; power of wind turbine.

\section{INTRODUCTION}

At present, in the world operated fleet of wind power plants, horizontal-axial or, so-called propeller type installations make up more than $90 \%$.

The lag in the development of vertical-axis wind turbines (VAWT), despite their advantages, as absence of aerodynamic noise, starting at low wind speeds and independence from wind direction, is caused by several reasons. A wind generator with a vertical axis of rotation was invented later by horizontal-axial propeller. In addition, the main disadvantage of vertical wind generators was mistakenly considered that for them it is impossible to obtain a ratio of the maximum linear velocity of the working bodies (blades) to wind speed greater than 1 (for horizontal-axis propeller wind turbines this ratio is more than 5: 1), which necessitated the use of multiplier systems or more massive low-speed generators [1].

There are exist such types of vertical-axial wind turbines: the Savonius rotor, the Darrieus turbine and the Darrieus H-rotor (Fig. 1).

The main advantage of vertical-axial wind turbines over horizontal-axial is their independence to the direction of the wind. Vertical-axial wind turbine with correctly calculated aerodynamics and geometrical relationships, is capable of self-starting at any direction of the wind, whereas, high power propeller type wind turbines at some angles of inward wind flow relative to the working plane of the windwheel, an additional source of energy is needed to remove the wind turbine's gondola to the wind or change the angle of attack of the blades.
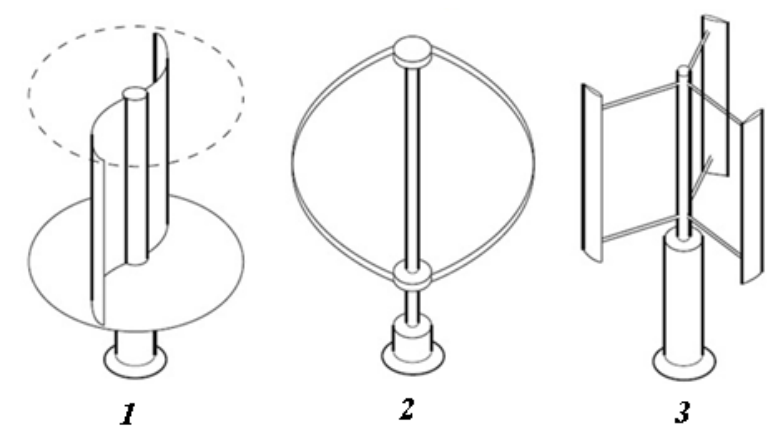

Fig. 1. Types of vertical axial wind turbines:

1 is the Savonius rotor; 2 is the Darrieus turbine; 3 is the Darrieus H-rotor

Coefficient of wind utilization of vertical wind turbines of industrial type (Darrieus H-rotor is considered), varies in the range $0.28-0.40$. This value is slightly less than horizontal-axial, but the design of these wind generators is simpler.

This paper is dedicated to investigations the efficiency of VAWT at different wind speeds, depending on the angle of attack of the rotor blades.

\section{PROBLEM STATEMENT}

Due to the fact that that mentioned above, vertical axial wind turbines by its energy characteristics lag behind horizontal-axial wind turbines, so the task is to investigate the effect of the changing value of the angle of attack of the blade on the power coefficient of the wind turbine.

These investigations would allow us to develop new principles for constructing vertical-axial wind turbines with a variable angle of attack of the blades in order to increase the energy efficiency of VAWT. 


\section{PROBLEM SOLUTION}

One way to adapt the properties of a wind turbine to changing wind conditions can be method of power control of wind turbine by changing the angle of attack of the blades.

During the circular motion, the Darrieus rotor blade operates in a periodically changing in nonstationary flow. The projection of the resultant aerodynamic force arising during the airfoil flow of blade profile to the circular trajectory of the blade gives the force that creates the torque on the shaft of the wind turbine. Since typical blade profiles are used for designing blades, the main parameter that determine the magnitude and direction of the force acting on the profile, is called the angle of attack. The nature of the motion of the blade in the rotor with a fixed position of the blades is such that on a very large part of its trajectory the angles of attack become supercritical. This leads to a breakdown of the flow and a sharp decrease in the value of the useful component of the aerodynamic force so that on some sections of the trajectory the blade even brakes the wind turbine [2]. However, if it is possible to simulate the rotor at various angles of attack, that the airfoil flow of the blade occurs at the optimum angle, it is possible significantly increase the value of the torque on the axis of the rotor.

During the modeling we used the viscous gas flow model with averaging of turbulent characteristics (Reynolds-averaged Navier-Stokes equations for an incompressible fluid)

$$
\begin{gathered}
\frac{\partial u_{j}}{\partial x_{j}}=0 \\
\frac{\partial u_{j}}{\partial t}+\frac{\partial\left(u_{j} u_{i}\right)}{\partial x_{j}}=-\frac{\partial p}{\partial x_{i}}+\frac{\partial}{\partial x_{j}}\left[v_{e f f}\left(\frac{\partial u_{i}}{\partial x_{j}}+\frac{\partial u_{j}}{\partial x_{i}}\right)\right]
\end{gathered}
$$

where $x_{i}, i=1,2$ is Cartesian coordinates $(x, y) t$ is time; $u_{i}$ is the projection $(u, v)$ of the average velocity on the Cartesian coordinate axes; $p$ is pressure; $\rho$ is density; $v_{\text {ef }}=v+v_{t}$ is effective coefficient of kinematic viscosity; $v$ и $v_{t}$ is molecular and turbulent coefficients of kinematic viscosity.

Boundary conditions (BC).

For the side surface of the blade $G \mathrm{BC}$ are defined by expression:

$$
\vec{U}_{x, y \in G}=\vec{\omega} \times \vec{r} ; \quad\left(\frac{\partial p}{\partial n}\right)_{x, y \in G}=0,
$$

where $\vec{r}=\{x, y\}$ is vector-radius of the point on the blade surface $G ; n$ is a normal to the blade surface $G$.
Conditions for the input boundary of a parallelepiped:

$$
U_{x}=U_{\infty} ; U_{y}=0 ; p=p
$$

For the initial boundary of a parallelepiped the Neumann conditions are performed:

$$
\frac{\partial U_{x}}{\partial x}=0 ; \quad \frac{\partial U_{y}}{\partial y}=0 ; \frac{\partial p}{\partial x}=0 ; \frac{\partial p}{\partial y}=0 .
$$

For the lateral boundaries of the parallelepiped, the reflection conditions are performed:

$$
\frac{\partial U_{x}}{\partial n}=0 ; \quad \frac{\partial U_{y}}{\partial n}=0 ; \quad \frac{\partial p}{\partial n}=0,
$$

where $n$ is a normal to the boundary of the region.

Using the following equations, for calculating the power coefficient on the wind velocity range for each rotor, tip speed ratio (TSR) and torque coefficients are used. In order to find the torque coefficient for each turbine, we must first calculate the swept area of the rotor using equation

$$
A=D H
$$

where $H$ is rotor height in $m$ and $D$ is overall diameter in $m$. A swept area schematic is shown below (Fig. 2).

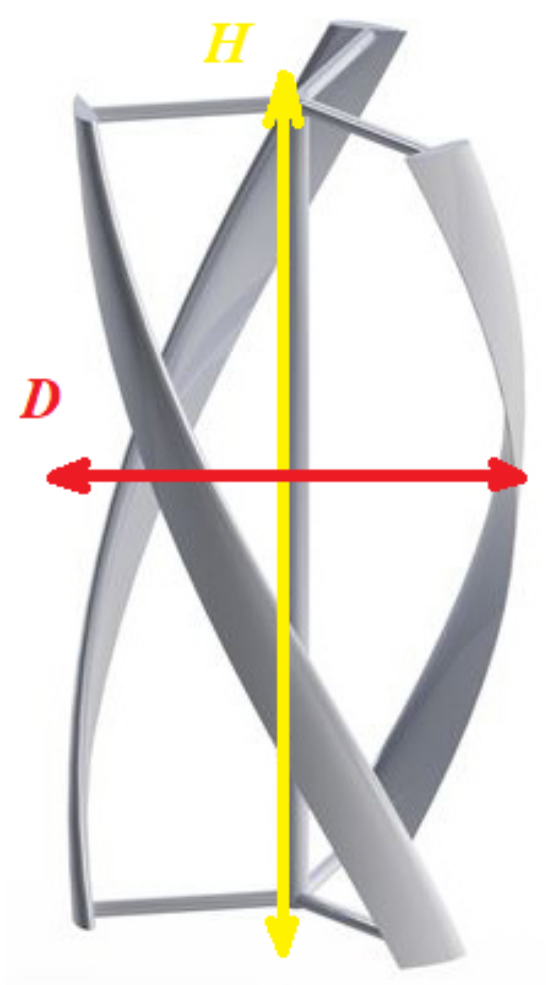

Fig. 2. A swept area of wind turbine

The swept area is used as a reference value for solving torque coefficients. The nondimensional torque coefficient is calculated using equation: 


$$
C_{m}=\frac{T}{\frac{1}{4} \rho A D V^{2}},
$$

where $T$ is a torque in $\mathrm{N} \cdot \mathrm{m}$; $\rho$ is air density in $\mathrm{kg} / \mathrm{m}^{3}$; $A$ is a rotor area in в $\mathrm{m}^{2} ; V$ is an air velocity $\mathrm{m} / \mathrm{s}^{2}$.

The nondimensional term for comparing efficiency of VAWTs is the power coefficient. First the angular velocity of the rotor must be calculated by equation

$$
\omega=\frac{2 \pi N}{60},
$$

where $N$ is the measured rotations per minute. Once the angular velocity is determined, the tip-speed ratio of the rotor is solved from equation

$$
\gamma=\frac{\omega D}{2 V} .
$$

The power coefficient is then calculated. As can be seen by equation, the power coefficient is found from the product of tip-speed ratio and torque coefficient.

$$
C_{p}=\frac{P}{0.5 \rho A V^{3}}=\frac{T \omega}{0.5 \rho A V^{3}}=\gamma C_{m} .
$$

Power $P$ of wind turbine is calculated by equation

$$
P=\frac{\left(\rho 2 R C_{p} V^{3}\right) \cdot 0.9}{2},
$$

where $\rho$ is air density, $R$ is a radius of wind turbine, $C_{p}$ is power coefficient, $V$ is air velocity, 0.9 is transformation coefficient of electric generator.

Because the investigations in the wind tunnel are very expensive, we simulated the wind turbine rotor in the Ansys software, using the Fluid Flow (Fluent) tool.

For each changing the angle of attack of the blades, 3D model was created (Fig. 3), which was sampled using an instrument Ansys Meshing (Fig. 4).

Using software Ansys it is possible to obtain the value of torque coefficient $C_{m}$, on the basis of which the power of the wind turbine is calculated. Dimensionless coefficients are used for comparison with other similar investigations and for testing the experiment. For this study, three dimensionless quantities are considered. The power coefficient describes the energy conversion efficiency of the turbine. The torque coefficient is a dimensionless representation of the torque that is proportional to the output. The TSR is defined as the ratio of the speed of the end of the blade to the speed of the wind.

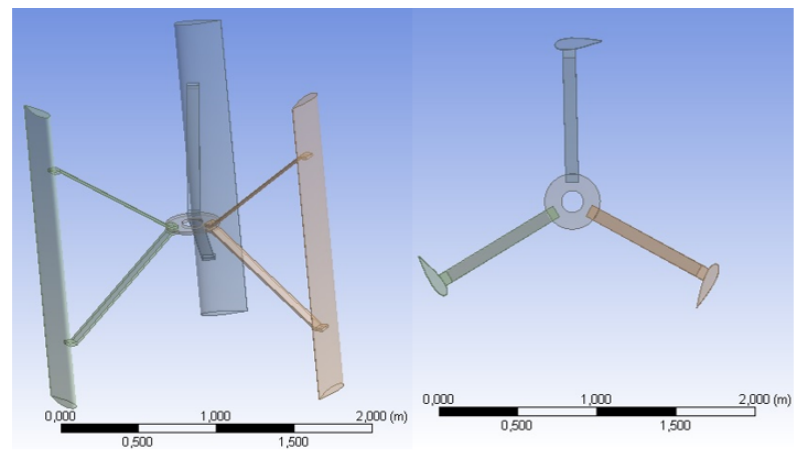

(a)

(b)

Fig. 3. 3D model of investigated wind turbine: (a) side view; (b) top view

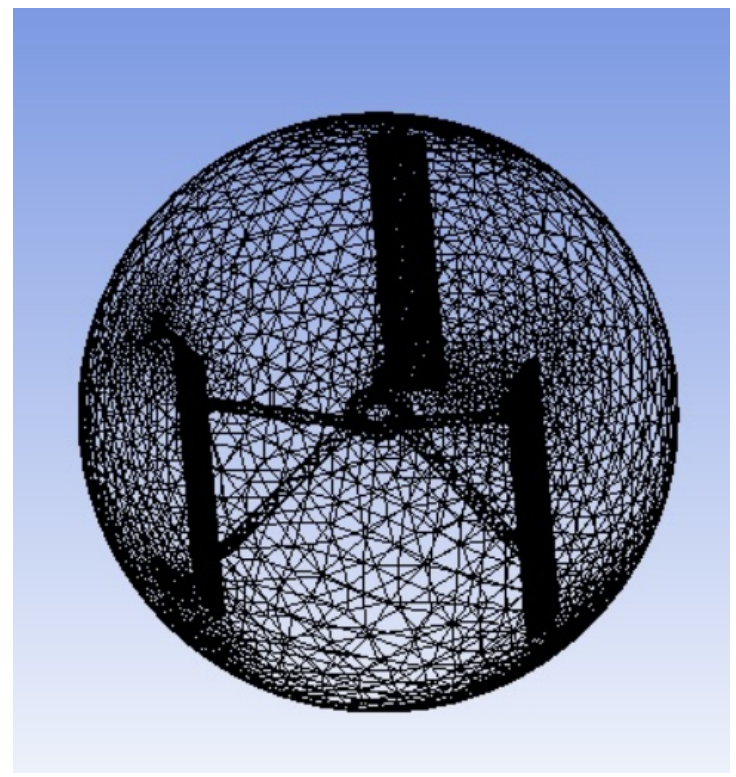

Fig. 4. Sampled model

The object of the investigation was a three-bladed Darrieus rotor. The rotor was tested 30 times with a change in the angle of attack $\lambda$ of the blade (Fig. 5) in the range from 0 to 10 degrees in steps of 2 degrees and with a change of wind speed in the range from 4 to $12 \mathrm{~m} / \mathrm{s}$, respectively.

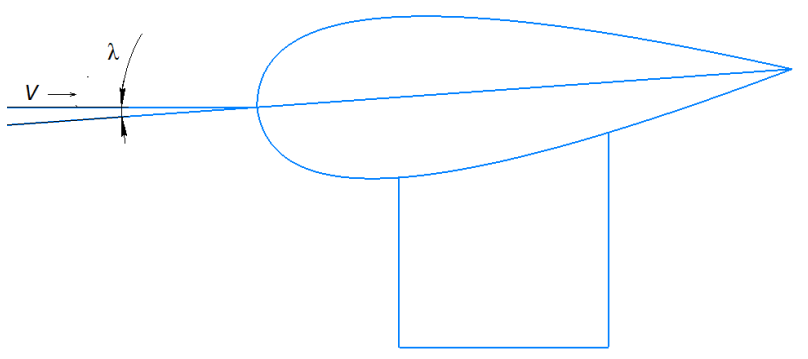

Fig. 5. Schematic representation of the angle $\lambda$

The resulting graphs of the effect of changing the angle of attack $\lambda$ on the power of the wind turbine represented on Fig. 6 (power is calculated using equation (11)). 


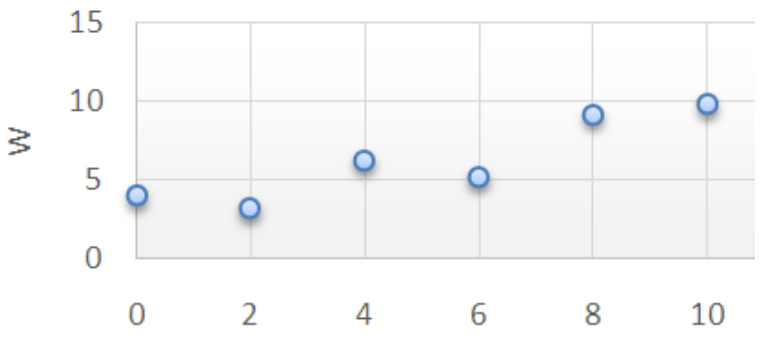

(a)

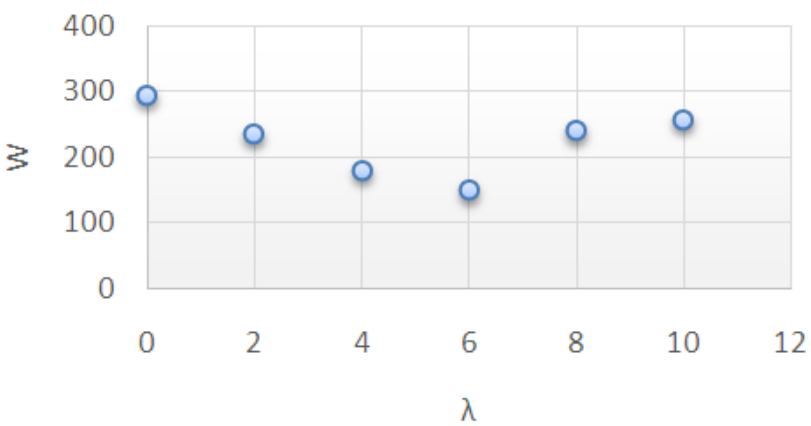

(c)

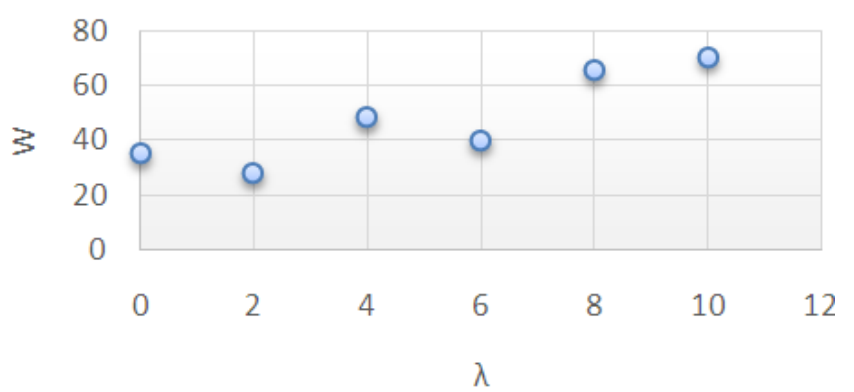

(b)

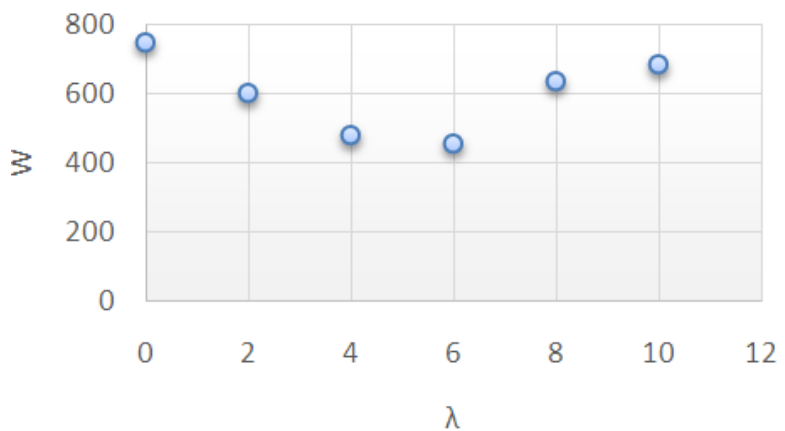

(d)

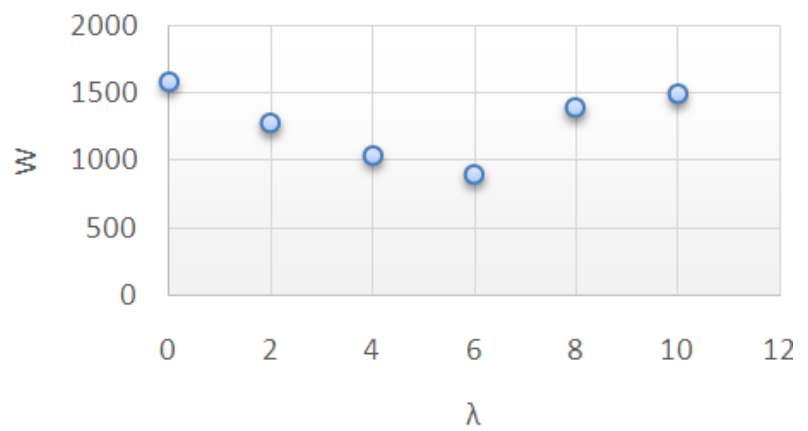

(e)

Fig. 6. The graph of the dependence of the power of the wind turbine (in Watts) on the angle $\lambda$ at wind velocity: (a) $4 \mathrm{~m} / \mathrm{s}$, (b) $6 \mathrm{~m} / \mathrm{s}$, (c) $8 \mathrm{~m} / \mathrm{s}$, (d) $10 \mathrm{~m} / \mathrm{s}$, (e) $12 \mathrm{~m} / \mathrm{s}$

\section{CONCLUSION}

After processing the experimental data from the Ansys software, we can conclude that at the low wind speeds (up to $6 \mathrm{~m} / \mathrm{s}$ ) the maximum power can be obtained at the angle $\lambda$ value of $8-10$ degrees. At high wind speeds (more than $6 \mathrm{~m} / \mathrm{s}$ ), an increase in of angle $\lambda$ value leads to a braking of the rotor of the wind turbine, which negatively effects on the power of the wind power plant.

\section{REFERENCES}

[1] J. Twydell, and A. Weir, Renewable energy sources: Trans. with English. Moscow: Energoatomizdat, 1990, $392 \mathrm{p}$.

[2] V. A. Dzenzersky, S. V. Tarasov, and I. Yu. Kostyukov, Low power wind turbines. Kyiv: Naukova Dumka, 2011, 590 p.

Received January 22, 2018

Sineglazov Victor. Doctor of Engineering Science. Professor.

Aviation Computer-Integrated Complexes Department, Education \& Scientific Institute of Information-Diagnostics Systems, National Aviation University, Kyiv, Ukraine.

Education: Kyiv Polytechnic Institute, Kyiv, Ukraine, (1973).

Research area: Air Navigation, Air Traffic Control, Identification of Complex Systems, Wind/Solar power plant.

Publications: more than 600 papers.

E-mail:svm@nau.edu.ua 
Shvaliuk Ihor. Master.

Aviation Computer-Integrated Complexes Department, Educational \& Research Institute of Information and Diagnostic Systems, National Aviation University, Kyiv, Ukraine.

Research area: Wind/Solar power plant.

Publications: 2.

E-mail: shvaluk95@gmail.com

В. М. Синсглазов, І. С. Швалюк. Дослідження впливу величини кута атаки лопаті на потужність вертикально-осьової вітроенергетичної установки

У даній роботі досліджено ефективність роботи вертикально-осьової вітроенергетичної установки, при різних швидкостях вітру в залежності від кута атаки лопатей ротора. Об'єктом дослідження був трилопатевий ротор типу Дар'є. При моделюванні використовувалася модель потоку в'язкого газу з усередненням турбулентних характеристик (усереднені по Рейнольдсу рівняння Нав'є-Стокса для нестисливої рідини). Проведені дослідження дозволять розробити нові принципи побудови вертикально-осьових вітроустановок із змінним кутом атаки лопатей з метою підвищення енергетичної ефективності станції.

Ключові слова: вертикально-осьовий ротор; ротор Дар'є; кут атаки; потужність вітроустановки.

Синсглазов Віктор Михайлович. Доктор технічних наук. Професор.

Кафедра авіаційних комп'ютерно-інтегрованих комплексів, Навчально-науковий інститут інформаційнодіагностичних систем, Національний авіаційний університет, Київ, Україна.

Освіта: Київський політехнічний інститут, Київ, Україна (1973).

Напрям наукової діяльності: аеронавігація, управління повітряним рухом, ідентифікація складних систем, вітроенергетичні установки.

Кількість публікацій: більше 600 наукових робіт.

E-mail: svm@nau.edu.ua

Швалюк Ігор Сергійович. Магістр.

Кафедра авіаційних комп’ютерно-інтегрованих комплексів, Навчально-науковий інститут інформаційнодіагностичних систем, Національний авіаційний університет, Київ, Україна.

Напрям наукової діяльності: вітрова та сонячна енергетика.

Кількість публікацій: 2.

E-mail: shvaluk95@gmail.com

В. М. Синєглазов, И. С. Швалюк. Исследование влияния величины угла атаки лопасти на мощность вертикально-осевой ветроэнергетической установки

В данной работе исследовано эффективность работы вертикально-осевой ветроэнергетическо установки, при различных скоростях ветра в зависимости от угла атаки лопастей ротора. Объектом исследования был трехлопастной ротор типа Дарье. При моделировании использовалась модель потока вязкого газа с усреднением турбулентных характеристик (усредненные по Рейнольдсу уравнения Навье-Стокса для несжимаемой жидкости). Проведенные исследования позволят разработать новые принципы построения вертикально-осевых ветроустановок с изменяемым углом атаки лопастей с целью повышения энергетической эффективности станции.

Ключевые слова: вертикально-осевой ротор; ротор Дарье; угол атаки; мощность ветроустановки.

Синеглазов Виктор Михайлович. Доктор технических наук. Профессор.

Кафедра авиационных компьютерно-интегрированных комплексов, Учебно-научный институт информационнодиагностических систем, Национальный авиационный университет, Киев, Украина.

Образование: Киевский политехнический институт, Киев, Украина (1973).

Направление научной деятельности: аэронавигация, управление воздушным движением, идентификация сложных систем, ветроэнергетические установки.

Количество публикаций: более 600 научных работ.

E-mail: svm@nau.edu.ua

Швалюк Ігорь Сергеевич. Магистр.

Кафедра авиационных компьютерно-интегрированных комплексов, Учебно-научный институт информационнодиагностических систем, Национальный авиационный университет, Киев, Украина.

Направление научной деятельности: ветровая и солнечная энергетика.

Количество публикаций: 2.

E-mail: shvaluk95@gmail.com. 